\title{
The Golden Rule in the Course of Time: Charitable Foundations in England, Germany and the EU Philanthropic Governance Perspective - of Altruism and Calculation
}

\author{
By Nina Christiane Lück*
}

The aim of this paper is to analyse the development of the so-called third sector in exemplary historical epochs and thereby contribute to the comparative legal analysis of charitable foundations which has emerged as a new research area. ${ }^{l}$ After giving a short overview of the development of the legal framework of charitable foundations, the paper will illustrate philanthropic ideas that were prevalent during each epoch. It will show how the conception of charities has changed during the course of time and how this links in with the comprehension of philanthropic governance that we find in today's Europe. The essay will focus on the English and the German third sector in order to elaborate on the differences and similarities between a classical common law country and a classical civil law country. It will be argued that in the light of the ongoing controversial debate about the Europeanisation of private law, an ever closer European Union and a community of values and common heritage ${ }^{2}$, cross-border giving can amount to an engine of creating a common European philanthropic landscape and thereby make a substantial contribution to turning round inertia and the lack of enthusiasm about the European project.

Keywords: Charitable foundations, European philanthropic landscape, Third sector, Philanthropic ideas.

\footnotetext{
*Lecturer, University of Sheffield, UK.

${ }^{1}$ I am grateful to Anne-Marie Schmitt who despite "this Sea between us" remains an invaluable dialogue partner and friend and I am grateful to my colleague Kate Bracegirdle for all her comments.

${ }^{2}$ Alineas 2 and 3 of the Preamble of the Charter of Fundamental Rights of the European Union state: "Conscious of its spiritual and moral heritage, the Union is founded on the indivisible, universal values of human dignity, freedom, equality and solidarity; it is based on the principles of democracy and the rule of law. It places the individual at the heart of its activities, by establishing the citizenship of the Union and by creating an area of freedom, security and justice. The Union contributes to the preservation and to the development of these common values while respecting the diversity of the cultures and traditions of the peoples of Europe as well as the national identities of the Member States and the organisation of their public authorities at national, regional and local levels; it seeks to promote balanced and sustainable development and ensures free movement of persons, goods, services and capital, and the freedom of establishment."
} 


\section{Introduction}

While in times of austerity, bailout funds, high unemployment and severely bad future perspectives, especially for younger people in some member states of the European Union (EU), we face persistent scrutiny and distrust towards the European Union ${ }^{1}$, there is a tentative, diffident trickle of cross-border giving that is likely to turn into a stream and thereby spill-over to a new form of European identity and European civil society. EU member states have a strong tradition of the "ethics of reciprocity" that has only reached a temporary standstill in the pre- and post-war, war times and during the communist era in some member states. With England and Germany, two EU countries have developed a third sector that makes a significant contribution to the tasks that would be deemed to fall within the responsibility of government or public authorities of the modern welfare states. ${ }^{2}$ Anheier and Daly conceptualise the role of charitable foundations as the following: complementarity, substitution, redistributive role, innovation, social and policy change, preservation of traditions and cultures, promotion of pluralism. ${ }^{3}$ While the history of non-profit governance in England and Germany shows some differences that do not rest only on the common law / civil law divide, in postwar times, both countries have faced a rise in numbers of charities or charitable foundations ${ }^{4}$ and both countries have hosted community foundations, neighbourhood initiatives and grass-root movements that have left domestic grounds and emerged as an intra-European phenomenon. Brussels and Brussels-located non-governmental organisations (NGOs) have taken up the opportunity for the promotion of legislation. A proposal for a Council regulation on the statute for a European Foundation (FE) is underway to acknowledge cross-border giving and charity activities within the European Union. ${ }^{5}$ This paper will look at the historical development of philanthropy in both countries and find out if the latest appearance of a philanthropic landscape within the EU has the power to pave the way for a European civil society that avows itself to a feeling of European citizenship, European identity, participation and self-determination.

\footnotetext{
${ }^{1}$ http://ec.europa.eu/public_opinion/archives/eb/eb77/eb77_first_en.pdf $\quad$ (accessed on 28/06/2014).

${ }^{2}$ What is described as "Komplementärfunktion" (complementarity function) in non-profit law is highly controversial in itself. While we all do appreciate third sector activities, it is dangerous not to insist on public authority fulfilling all functions that are connected to the modern social welfare state.

${ }^{3}$ Anheier and Daly (2007) 11-14.

${ }^{4}$ For detailed figures please see: http://ec.europa.eu/internal_market/company/ docs/eufoundation/feasibilitystudy en.pdf (accessed on 28/6/2014).

${ }^{5}$ http://www.europarl.europa.eu/meetdocs/2009_2014/documents/com/com_com(2012)0035/c om_com(2012)0035_en.pdf (accessed on 28/6/2014).
} 


\section{The Common Law - Civil Law Divide}

Even though the good foundation governance elements exist in both the English and the German philanthropic landscape, some remarkable differences that stem from the common law - civil law divide to some extent prevail, as well. These differences also have to do with an incongruent understanding of the role that charitable foundations or charities have. One very notable difference is that England looks at the concept of charitable purpose from a property law perspective whereas German charity law determines charitable purposes (Gemeinnützigkeit) in terms of tax law and tax exemptions. Before going back to the beginning of the idea of charities, the current concept of charities and charitable foundations needs a closer look.

\section{The Concept of "Charities" and "Charitable Foundations" in England and Germany}

Today's philanthropic landscape in England and Germany shows that there is a difference in the legal framework that "acting for a good cause" is provided for. As of today, there are approximately 12.000 foundations with a charitable status in Germany, meaning their statutes and constitutions are governed by sections $\S \S 80-88$ of the German civil code (BGB). All in all, there are approximately 20.000 foundations. While the density of the regulation for foundations appears to be relatively low measured by the German affinity for regulation and taking the content of sections $\S \S 80-88$ BGB into consideration, the English philanthropic landscape supplies a much broader concept of "charities" with England and Wales having more than 160.000 charities. ${ }^{1}$ For a charity under English law, no specific legal form is required that can be deemed as an equivalent to the "charitable foundation" under German law. The forms of an English charity can have range from an unincorporated association, a company limited by guarantee and a charitable company to a (charitable) trust and to the most recently established legal form - a charitable incorporated organisation $(\mathrm{CIO}){ }^{2}$ If the structural elements and legal requirements (a managing board as compulsory organ, a comparatively high minimum initial capital $^{3}$ to set up a charitable foundation, a legal personality under civil law) that are constitutive for a charitable foundation under German law, were applied to the English charity landscape, approximately 9.000 charities with the

\footnotetext{
${ }^{1}$ England and Wales are administered by the same independent government department, the Charity Commission. Scotland and Northern Ireland have counterparts, the Office of the Scottish Charity Regulator and the Charity Commission of Northern Ireland. Further information can be found on the respective webpages of the three monitoring bodies. www.charity-commission.gov .uk; www.oscr.org.uk; www.charitycommissionni.org.uk ${ }^{2} \mathrm{Cf}$. in detail Picarda (2010) 185 .

${ }^{3}$ According to the state laws that flank the German civil code's provisions on charitable foundations, a minimum of $€ 25.000$ in some Länder (states) of Germany is needed and in others, a minimum of $€ 50.000$ is needed. Once the charitable foundation is established and approved of by the public authority, this asset ("Grundstock") cannot be used anymore and has to be preserved and maintained by all means.
} 
framework of a German charitable foundation exist in England and Wales. ${ }^{1}$ This distinction is noteworthy for today's philanthropic landscape as defining the scope of charitable foundations and, inter alia, crucial when discussing the European foundation. Anheier and Daly ${ }^{2}$ have elaborated that the definition of foundations varies considerably from one country to the next in several dimensions. However, there are also some striking similarities - in the historical development.

\section{Approaching the Concept of Non-profit Governance}

The terms philanthropic governance or good foundation governance and non-profit governance stem from business and management and questions that relate to the control and the organisation of business entities. Governance is therefore a much broader concept than management. Governance embraces the distribution of rights and responsibilities of the participants such as the board, the managers, the shareholders; external and internal stakeholders. ${ }^{3}$ The entire discipline "corporate governance" has been of both theoretical and practical relevance for measuring the quality and success within corporations and continues to seek answers in times of financial scandals, the banking crisis, bankruptcy and credit crunch. Governance therefore also has an organisational steering function and is linked to accountability and transparency. The whole corporate governance system has had spill-over effects to the non-profit sector. As latest scandals have shown, the third sector is not immune against fraud, money laundering and nepotism in general. ${ }^{4}$ In the nineties, US researchers have developed various non-profit governance models that had the aim of addressing the very specific governance aspects that arise within non-profit organisations. ${ }^{5}$ In the meantime, the discussion has entered the European third sector. Non-profit governance can therefore be defined as the overall and strategic dealing with economic, meta-economic and content-related variables and as normative framework for the management in non-profit organisations in order to strike the balance between stakeholders. The stakeholders in nonprofits are a very heterogeneous group of internal and external stakeholders that embrace employees, voluntary workers, directors/managers, advisors, auditors and partners like solicitors and tax consultants, trustees, public authorities, inland revenue office, tenants as well as landlords, other non-profit organisations, the founder(s), people making donations, the individuals or organisations that are beneficiaries and the numerous service providers such as

\footnotetext{
${ }^{1}$ Cf. The final report of the feasibility study on a European Foundations Statute: http://ec.europa.eu/internal_market/company/docs/eufoundation/feasibilitystudy_en.pdf, (accessed on 28/6/2014) 19.

${ }^{2}$ Anheier and Daly (2007) 8 .

${ }^{3}$ Anheier (2005) 231.

${ }^{4}$ Both in England and Germany, there have been cases of mismanagement, luxurious board meetings, "secret" salaries and cases of interpreting tax provisions far beyond their wording. As a response to that, code of conducts and principles of best practice arose that, however, often lack a binding nature and enforcement mechanisms.

${ }^{5}$ Harris (1993); Chait, Holland and Taylor (1996); Carver (1997).
} 
web administrators, marketing firms and non-profit journals. In the course of history, those stakeholders face changing roles and responsibilities.

\section{From pia causa to Grass-Root Movements}

In order to analyse the development of philanthropy, a rough classification of historical epochs will be chosen due to limits of space. The first phase embraces pre-Christian Antiquity until the Middle Ages, the second phase contains examples from the Early to the Late Middle Ages, the third phase looks at the era of Enlightenment and secularisation and the last phase highlights developments from the 19th century to our present time.

\section{Antiquity: From Death Cult and Salvation to pia causa}

In medieval times, the development of charitable foundations is similar when looking at the role the church had. However, in pre-Christian Greek and Roman times, the concept of a charitable foundation is not known as such. Originally, there was not a word in neither ancient Greek or in Latin for the verbs donate or found. Whereas the altruistic concept of giving is developed much later, a more egoistic concept of donations in connection to mortuary cults is a prevailing pattern during antiquity. This direct link can be illustrated by the Greek verb philotimeisthai (to strive for honour) that was given the connotation of donate or found. In pre-Christian Greece, Egypt and Rome, ideas of charity played a minor role. This only changed with the beginning of Christianity where pia causa (the pious purpose) becomes a dominant motivation to do something good for others. Though not entirely altruistic, for the underlying motivation to give for piam causam was to secure oneself a place in the kingdom of heaven. However, giving is never entirely altruistic, not then and not nowadays. When people are active in the third sector nowadays, they also act "for" themselves. ${ }^{1}$ The New Testament contains numerous allegories of helping the needy, ill and weak ones, the most prominent parable being Luke 10, 25-37: The Good Samaritan, who helped an injured traveller lying by the roadside after he had been robbed and beaten. While both a priest and a Levite had walked by, ignoring the man who needed help, the Samaritan stops and helps the man. He washes the man's wounds, helps him to sit on his donkey and transports him to a hostel and pays the hostel the next day out of his own pocket. He leaves the place saying to the man who runs the hostel that on his return he would pay the extra costs that might have been incurred. It is believed that Jesus told this parable as a response to the question of how to identify or treat neighbours as mentioned in Leviticus 19:18. ${ }^{2}$ The benevolence of Christian congregations also embraced putting aside so-called deposita pietas from the property. Those items were

\footnotetext{
${ }^{1}$ For a concise analysis of the factors that motivate people to act for a charitable purpose, see Anheier (2010) 6 et seq.

${ }^{2}$ Leviticus 19:18: "Do not seek revenge or bear a grudge against anyone among your people but love your neighbours as yourself. "
} 
used for charitable purposes and amount to the beginning of charitable foundations as we know them today.

A milestone for the history of charities is the Codex Justinianus that was issued by Eastern Roman Emperor Justinian I between 529 and 534 and that contained several provisions that relate to dispositions by will that are done for a charitable purpose. In this early codification of Roman law, infirmaries, almshouses and orphanages are grouped as institutions of "piae causae". However, there is no consequent protection of the institutions as such in Justinian's time as in terms of governance, the code does not solve the conflict of interests between what we would contemporarily describe as stakeholders: founders and donators, their heirs, and an ever stronger growing figure, the bishop. The beneficiaries, that are deemed stakeholders in modern third sector studies, were not seen as a group to be borne in mind in the decision-making process in those days.

\section{The Middle Ages: A Rag Rug}

In the early middle Ages, a network of hospitals connected to monasteries developed alongside institutions that took care of the poor, the ill and the foreign. One central well-known figure in this respect is Saint Benedict of Nursia (480-543) who is seen as the founder of Western monasticism. The Rule of St Benedict called Sancti Benedicti Regula Monasteriorum is of both administrative and spiritual nature. Whilst the administrative part deals with the "governance" within the monastery, the spiritual part explains how to be a good Christian. Care and welfare for the needy are a central element in St Benedict's rules and standards. ${ }^{2}$ However, it cannot be said that following from this early charity network a stable system of charity organisations or charity activities emerged. The turbulences that a period of migration, throne wars and the Norman conquest of England in 1066 brought about hindered the establishment of a persistent charity system both on the continent and in England. Nevertheless, there are some examples of a gradually developing system of charities. In Augsburg, the merchant Jakob Fugger (1459-1525) whose family had originally gained enormous wealth by running cottonspinning mills in Italy and later on held a monopolist position in both the European copper and financial sector, played a pivotal role in the start of developing a system of charitable foundations. He set up three charitable foundations that had one governing deed (1521); the most well-known being the Fuggerei, a settlement consisting of several almshouses, hospitals and foodbanks for craftsmen and day labourers. The Fuggerei is known as the hugest settlement of social housing and preserved carefully. As of today, 150 families live in the Fuggerei. They are - in accordance with the 1521 deed needy Catholic families from Augsburg that pay a symbolical rent of less than one Pound a year which is the equivalent of a former Rhenish gulden. ${ }^{3}$

\footnotetext{
${ }^{1}$ Liermann (1963) 35.

${ }^{2}$ Liermann (1963) 48.

${ }^{3}$ http://www.fugger.de/en/singleview/article/unparalleled-worldwide-for-500-years/ 1.html (accessed on June 28/06/2014)
} 
In England, with the beginning of reformation, a whole body of rules concerning charitable trusts paved the way for modern charity law. Originating from Code Justinian and becoming a firm element of ecclesiastical law, the $c y$ près doctrine played an important role in the jurisprudence as it grants courts the power to alter the purpose of a charitable trust when it was held that the initial purpose was either impossible or unlawful. ${ }^{1}$ Courts thereby have the capacity to redefine the terms of a charitable trust so that it is as close as possible ("cy-près") to the original intention of the testator. Under German Stiftungsrecht, determining whether the charitable purpose has been reached or fulfilled (Zweckerreichung) or whether reaching the purpose must be seen as having failed for good (Zweckverfehlung) is rather a matter for the public authority that monitors charitable foundations in each of the sixteen federal states. It happens only under very narrow circumstances and for the adjustment of the purpose (Zweckanpassung), the founder's consent or that of his heirs is needed. ${ }^{2}$

As time proceeded, the bishop had an ever-growing political power, his task was not only to direct and lead the congregation and to represent it but also to administer and monitor all financial aspects. Therefore, it was the bishop in this time who could be seen as an early form of managing director for charities. Property given away for piam causam was seen as property of the church, res ecclasiastica. ${ }^{3}$ Wealthier members of a congregation were asked to give away a considerable percentage of their wealth, not necessarily for the benefit of the needy but for the repair of churches and the maintenance of church institutions which indirectly benefitted the needy that were living in hospitals or almshouses. Wealthy testators also used charitable dispositions for educational reasons and set up colleges in Oxford and Cambridge that still exist today. ${ }^{4}$ Governance-wise, there is evidently the issue that reaching the kingdom of heaven was closely linked to giving away parts of your wealth to the ecclesia, a mechanism that reminds of the system of selling of indulgences which led to Martin Luther publishing his 95 Theses in 1517. In 1562, selling indulgences was banned by the Catholic church itself and even led to excommunication a couple of years later. Whereas Reformation in Germany from 1517 until 1648 had a strong theological focus, English Reformation was much more political and led to the period of Restoration of the English monarchy (1660-1688).

\section{From Enlightenment and Secularisation to Industrial Revolution}

Reformation and the seizure of Tudor dynasty in 1603 meant a radical change for the philanthropic landscape in England as the new rulers abolished the acquisition of property by chantries and dissolved the monasteries. ${ }^{5}$ A key

\footnotetext{
${ }^{1}$ Picarda (2010) 192.

${ }^{2}$ Hopt (2010) 555.

${ }^{3}$ Liermann (1963) 32.

${ }^{4}$ Examples are the Oxford-located University College Oxford, founded in 1249, Balliol College which was founded in 1263 and Merton College which was founded in 1264.

${ }^{5}$ Cf. Leat (2001) 268.
} 
document for non-profit governance is the Elizabethan Statute of Charitable Uses of 1601, which forms part of the Poor Laws and marks the secularisation of philanthropy. This Statute aimed at preventing the abuses that had occurred with charitable trusts that are the master pattern for modern English charitable foundations. ${ }^{1}$ The Poor Laws were introduced not only to bring relief for the aged, the sick, children and orphans, they also demonstrate early ideas of an employment service for those that were healthy and looking for jobs. In the course of time, the Poor Laws distinguished clearly between undeserving and deserving poor and brought in a strong moral element. ${ }^{2}$ With the Mortmain ${ }^{3}$ Act of 1736, the age of associated philanthropy began. ${ }^{4}$ By this Act, leaving land to charities was only admissible under very narrow circumstances which led to testators handing their property down in various other ways.

Gradually, new forms of voluntary organisations with a charitable purpose flanked the traditional English charitable trusts. Wealthier citizens often liaised for a charitable cause which marks the beginning of modern grass-root movements; the only difference being that grass-root movements as we know them nowadays are no longer connected to a person's wealth or income.

In the Victorian Era of 1837 until 1901 the predominant model was that the upper and middle classes looked after the needy. The considerable growth of charities in cities such as London, Manchester and Liverpool that had started during the industrial era from 1750 onwards thus continued. ${ }^{5}$ Secularisation and industrialisation brought about a concise understanding that philanthropic purposes contributed to the well-being of society as a whole. There are numerous examples of industrialists that set up exemplary health care and educational systems for mill factory workers and their families, as it was understood that in the long run, such a pursuance led to increased productivity. Today, one example for 19th century philanthropy can be seen on the Industrial Site Saltaire which has been listed as a UNESCO World Heritage Site in 2001 and which is part of the European Route of Industrial Heritage. ${ }^{6}$ Industrialist Sir Titus Salt (1803-1876) set up a mill close to Bradford / West Yorkshire in 1851 that fabricated Alpaca wool and Russian Donskoi Wool. Some 3000 workers and their family members lived there. While not only providing decent housing, Salt also set up various other buildings such as a hospital, a church, a school, an almshouse, a park, little allotments and a community hall hosting a library, a concert house, a gym and swimming baths. UNESCO has confirmed that Saltaire is of outstanding universal value by the following description: "Saltaire is an exceptionally complete and well preserved industrial village of the second half of the 19th century, located on the river Aire. Its textile mills, public buildings, and workers' housing are built in a harmonious style of high architectural quality and the urban plan survives intact, giving a vivid

\footnotetext{
${ }^{1}$ Luxton (2001) 7.

${ }^{2}$ Anheier (2005) 29.

${ }^{3}$ Deriving from the Latin manus (capacity to buy and sell) mortua (inalienable, unable to be given). Mortmain therefore has the meaning of incapacity of selling possessions or estate.

${ }^{4}$ Luxton (2001) 8.

${ }^{5}$ Anheier (2005) 30.

6http://www.erih.net/index.php (accessed 28/06/2014)
} 
impression of the philanthropic approach to industrial management. The industrial village of Saltaire is an outstanding example of mid-19th century philanthropic paternalism, which had a profound influence on developments in industrial social welfare and urban planning in the United Kingdom and beyond." With regard to philanthropic paternalism, it is, however, also true that Salt's motivation to build the site in the way he did certainly combined a mixture of rational economic thoughts, governance elements and altruistic thinking. He saw that the "productivity" of his workers was higher if they enjoyed proper living conditions for themselves and their families, he also wanted some control over staff but he was nevertheless influenced by his Christian beliefs, just as Fugger, centuries earlier, who insisted that the residents of Fuggerei prayed three times a day. On German territory, where the era of Enlightenment and continuing secularization were hostile to charitable foundations, the liberal 19th century welcomes charitable foundations again and legal scholars such as Heise, von Savigny and Gierke engage in heated debate on the legal personality of charitable foundations. ${ }^{2}$

From the 19th Century to our Present Time: Disappearance, Strengthening and a New Understanding

The time before, in and after the two World Wars faced inflation and financial instability, the death of millions of people and a painful disappearance of charitable foundations. In Germany, the annulment and forced amendment of charitable purposes by authorities in order to provide capital for the war industry caused damage to the charity landscape. Particularly during World War II, Jewish charitable foundations were annulled or their purpose amended so that their new purpose fitted within the racial laws. ${ }^{3}$ In post-war Germany, there has been a gradual rise of charitable foundations since 1950 with the exception of the year of German Reunification 1990 and with the exception of the years 2002/2003. Since the mid-nineties, one charitable foundation is set up each day on average which has led to legal scholars talking about a philanthropic boom, a "Renaissance of philanthropy", a comeback of patronage and a competition in the culture of giving. ${ }^{4}$ Germany and England are both perceived as countries with a very strong third sector, which is supported by the total number of charitable foundations. ${ }^{5}$ In Germany, a new form of charitable foundation has gained a lot of popularity since the nineties: The Bürgerstiftung, which is a charitable foundation set up under the legal framework of sections $80-88$ of the civil code. There is not only one founder (whose name the charitable foundation often carries) but a group of people that wants to improve various conditions for the people that live in a certain area, often a town. Therefore, many towns in Germany carry the name of the town

\footnotetext{
${ }^{1}$ http://whc.unesco.org/en/list/1028 (accessed on 28/06/2014)

${ }^{2}$ Cf. Lück (2008) 42.

${ }^{3}$ see Rawert /Ajzensztejn (1998) 180, that provide a thorough study on the gradual disappearance of Jewish charitable foundations that were part of a distinct charity system in German society.

${ }^{4}$ Cf. Lück (2008) 21.

${ }^{5}$ Strachwitz (2001) 133; Leat (2001) 270.
} 
preceded by the word Bürgerstiftung in front of it as is the case with the Bürgerstiftung Weimar ${ }^{l}$. Bürgerstiftung Weimar was set up in 2004 by a group of citizens who contributed financially and are thus founders. Other people are welcome to contribute as well, hence the circle of founders keeps growing. By virtue of section 2 of its charter, the purpose of Bürgerstiftung Weimar is to support and develop projects in the area of education, for the care of the elderly, for young people, people with a migrant background as well as projects in arts, culture, sports and environmental protection all of which have a regional link and significance. There are more than 350 Bürgerstiftungen throughout the German Länder. From a socio-political point of view, there is an undeniable link with Bürgerstiftungen and self-determination, civil engagement and participation. ${ }^{2}$

By the end of the 19th century, a stable and friendly environment existed for charitable foundations in England. There have been legal as well as fiscal privileges for foundations and monitoring by the Charity Commission as the non-ministerial government department overseeing the charity sector. ${ }^{3}$ Socalled Community Foundations are the equivalent to Bürgerstiftungen. Community Foundations in England arose in the seventies for the first time and they were modelled on their American counterparts. They use a permanent endowment of charitable donations to make grants to local or community projects. $^{4}$

In an economic analysis of charity law, community foundations are seen as a reaction to the modern social welfare state withdrawing from many of its very own tasks, which is often described as "doing what the state doesn't do". Today, England's and Germany's strong third sectors make a substantial contribution to the European Research Area and the European labour market. ${ }^{5}$

On a European scale, the third sector has faced post-war growth and strengthening and after 1990, a gradual rise of charitable foundations in the acceding EU member states of central and Eastern Europe. ${ }^{6}$ There is a wide understanding that setting up, monitoring and engaging with charitable foundations is one, if not THE, tool for civil society to take part in decisionmaking processes and in the formation of democracy.

Even though the law of charitable foundations does not fall within Brussels' legislative competence, various EU institutions and lobby groups have put the European perspective of charity law on their agenda. In 2005, the European Commission recommended a code of conduct for non-profit organisations and the Commission has been a strong advocator of a European Foundation (Fundatio Europaea, FE). In its attempt to facilitate intra-EU donations for public benefit purpose, the Commission has been supported by

\footnotetext{
${ }^{1} \mathrm{http} / / / \mathrm{www}$.buergerstiftung-weimar.de/idee/ (accessed 2/07/2014)

${ }^{2}$ Cf. Adloff, Schwertman, Spengel and Strachwitz (2007) 174.

${ }^{3}$ see http://www.charitycommission.gov.uk (accessed 2/07/2014)

${ }^{4}$ Leat (2007) 100.

${ }^{5}$ http://ec.europa.eu/internal_market/company/docs/eufoundation/feasibilitystudy_en.pdf (accessed on 28/6/2014) 43.

${ }^{6}$ http://ec.europa.eu/internal_market/company/docs/eufoundation/feasibilitystudy_en.pdf, 18 et et seq. 27
} 
the European Foundation Centre (EFC), which is a membership association of some 230 foundations and corporate founders. ${ }^{1}$ The proposed European Foundation will not replace the existing legal framework for charitable foundations in the $28 \mathrm{EU}$ member states due to a lack of legislative competence on the part of Brussels. The FE will rather supplement the existing national laws to facilitate intra-EU donations and funding. The proposed FE has five key characteristics: it will have legal personality, a public benefit purpose, but no formal membership; there will be state supervision and it can only be established by registration. The current proposal had some identified shortcomings and the Greek EU presidency passed without addressing them in a way that a majority in favour of the proposal could be reached. The burden is now on Italy to deal with the shortcomings of the proposal and to reach an agreement between the member states.

Most importantly, the renewed European debate about philanthropic governance within the EU is an incentive for civil society to realise participation and thereby form a European voice for citizens who actively shape democracy.

\section{Conclusions}

A. Mercy, benevolence and acting for a charitable purpose are guiding themes throughout human history even though in different epochs and different cultures they might not have had the same meaning or weight.

B. The idea of charitable foundations as a way of "organising" doing something good for people in need slowly developed in early medieval times and came to various standstills in the course of history; however, the idea of philanthropy always prevailed.

C. As seen with the Fuggerei in Augsburg and the industrial site Saltaire in England, historical ideas of charity do not vanish in the course of time. They are present in our modern times, either as historical sites, even listed as UNESCO world heritage or because they still fulfil their function and operate according to their deed or founding statutes as is the case of Fuggerei. There is an undeniable overarching philanthropic element throughout the centuries.

D. There is a causal link between the beginning of the era of associated philanthropy and grass-root movements of our modern times. Grass-root movements play a significant role in participation, democracy and selfdetermination, and also a strong civil society.

E. The socio-political and legal environment that charitable foundations face provide a key in understanding how much emphasis a state or public authority places on the strength of a civil society. This is not to be understood as the welfare state being reluctant to organise its budget in a way so that it cannot escape the minimum support it has to provide.

F. While there are notable similarities in the early history of charitable foundations, there are a few differences between England and Germany that are

${ }^{1}$ http://www.efc.be (accessed 2/07/2014) 
as striking as differences are between a classical common and a classical civil law country. Those differences mainly concern the legal framework and not so much public authority's monitoring and the motivation that lies behind engaging in the third sector.

G. On the level of the EU, there is a flourishing philanthropic sector that despite austerity and Euroscepticism - has the power to make substantial changes to how European we feel.

\section{References}

Adloff, F., Schwertman, P., Spengel R., and Strachtwitz R. (2001), 'Germany', in: Anheier, H. K. and Daly, S. (eds.) (2007) The Politics of Foundations. A comparative analysis. Routledge, London and New York, pp. 172-185.

Anheier, H.K. (2005) Nonprofit Organizations. Theory, management, policy. Routledge, London and New York

Anheier, H. K., (2010) What kind of nonprofit sector, what kind of society? Comparative policy reflections', in: Hopt, K. J. and T. von Hippel.( eds.) (2010) Comparative Corporate Governance of Non-Profit. Organizations. Cambridge: Cambridge University Press. pp. 3-18.

Anheier, H.K. and S. Daly, (2007). 'Philantropic Foundations in Modern Society', in: Anheier, H. K. and Daly, S. (eds.) (2007). The Politics of Foundations. A comparative analysis. London and New York; Routledge, pp. 3-26.

Carver, J. (1997). Boards that Make a Difference: A New Design for Leadership in Nonprofit and Public Organisations. $2^{\text {nd }}$ ed., New York: Jossey-Bass, John Wiley

Centrum für soziale Investitionen und Innovationen/Max Planck Institute for Comparative and International Private Law: Feasibility Study on a European Foundation Statute, Final Report http://ec.europa.eu/internal_market/company/ docs/eufoundation/feasibilitystudy_en.pdf (last accessed on 28/06/2014)

Chait, R.P., Holland, T.P. and B.E. Taylor (1996), Improving the Performance of Governing Boards. Westport: Oryx.

European Commission, Public Opinion in the European Union, http://ec.europa.eu /public_opinion/archives/eb/eb77/eb77_first_en.pdf (accessed on 28/06/2014)

Harris, M. (1993). 'Clarifying the board rule: A total activities approach', in: Young, D.R., Hollister, R.M. and V. Hodgkinson (eds.) (1993). San Francisco, CA: Jossey Bass Publishers.

Hopt, K.J. (2010). 'The board of nonprofit organizations: some corporate governance thoughts from Europe' in: Hopt, K. J. and T. von Hippel (eds) (2010) Comparative Corporate Governance in Nonprofit Organizations. Cambridge: Cambridge University Press. pp. 351-562

Leat, D. (2001), Country Reports - United Kingdom, in: Schlüter, A., Then, V. and P. Walkenhorst, P. (eds.) (2001) Foundations in Europe. Directory of Social Change, London, pp. 268-281

Leat, D. (2007), 'United Kingdom', in: Anheier, H. K. and Daly, S. (eds.) (2007) The Politics of Foundations. A comparative analysis. London and New York: Routledge, pp. 96-114.

Liermann, H. (1963). Geschichte des Stiftungsrechts. 2. Auflage, unverändereter Nachdruck der ersten Auflage 1963, ergänzt durch ein Geleitwort von Axel Freiherr v. Campenhausen und einer Abhandlung von Michael Borgolte. Tübingen: Mohr Siebeck. 
Lück, N. (2008). Die Anwendbarkeit des Corporate Governance Kodex auf Stiftungen. Berlin: Uni-Edition.

Luxton, P. ( 2001). The Law of Charities. Oxford: Oxford University Press.

Picarda, H. (2010), 'Harmonising nonprofit law in the European Union: an English perspective and digest', in: Hopt, K. J. and T. von Hippel (eds) (2010). Comparative Corporate Governance in Nonprofit Organizations. Cambridge: Cambridge University Press. pp. 170-196

Rawert, P. and A. Ajzensztejn (1998) 'Stiftungsrecht im Nationalsozialismus. Eine Untersuchung unter besonderer Berücksichtigung der Jüdischen und paritätischen Stiftungen', in: von Campenhausen, A., Kronke, H. and O. Werner (1998), Stiftungen in Deutschland und Europa. Düsseldorf: IDW-Verlag.

Strachwitz, R. (2001), Country Reports - Germany, in: Schlüter, A., Then, V. and P. Walkenhorst. (eds.) (2001) Foundations in Europe. London: Directory of Social Change, pp. 133-144 
